\title{
Orality and Literacy revisited
}

\section{Citation}

Nagy, Gregory. 2015. "Orality and Literacy revisited." Classical Inquiries. http://nrs.harvard.edu/ urn-3:hul.eresource:Classical_Inquiries.

\section{Published Version}

https://classical-inquiries.chs.harvard.edu/orality-and-literacy-revisited/

\section{Permanent link}

http://nrs.harvard.edu/urn-3:HUL.InstRepos:40935346

\section{Terms of Use}

This article was downloaded from Harvard University's DASH repository, and is made available under the terms and conditions applicable to Other Posted Material, as set forth at http:// nrs.harvard.edu/urn-3:HUL.InstRepos:dash.current.terms-of-use\#LAA

\section{Share Your Story}

The Harvard community has made this article openly available.

Please share how this access benefits you. Submit a story.

\section{Accessibility}




\section{Classical Inquiries}

Editors: Angelia Hanhardt and Keith Stone

Consultant for Images: Jill Curry Robbins

Online Consultant: Noel Spencer

\section{About}

Classical Inquiries (CI) is an online, rapid-publication project of Harvard's Center for Hellenic Studies, devoted to sharing some of the latest thinking on the ancient world with researchers and the general public.

While articles archived in DASH represent the original Classical Inquiries posts, $C I$ is intended to be an evolving project, providing a platform for public dialogue between authors and readers. Please visit http://nrs.harvard.edu/urn-3:hul.eresource:Classical_Inquiries for the latest version of this article, which may include corrections, updates, or comments and author responses.

Additionally, many of the studies published in $C I$ will be incorporated into future CHS publications. Please visit http://nrs.harvard.edu/urn-3:hul.eresource:CHS.Online_Publishing for a complete and continually expanding list of open access publications by $\mathrm{CHS}$.

Classical Inquiries is published under a Creative Commons Attribution-NonCommercial 4.0 International License. Every effort is made to use images that are in the public domain or shared under Creative Commons licenses. Copyright on some images may be owned by the Center for Hellenic Studies. Please refer to captions for information about copyright of individual images.

\section{Citing Articles from Classical Inquiries}

To cite an article from Classical Inquiries, use the author's name, the date, the title of the article, and the following persistent identifier: http://nrs.harvard.edu/urn-3:hul.eresource:Classical_Inquiries.

For example:

Nagy, G. 2019.01.31. "Homo Ludens at Play with the Songs of Sappho: Experiments in Comparative Reception Theory, Part Four.” Classical Inquiries. http://nrs.harvard.edu/ urn-3:hul.eresource:Classical_Inquiries. 


\section{Classical Inquiries \\ Studies on the Ancient World from CHS}

Home About People

Home $»$ By Gregory Nagy » Orality and Literacy revisited

\section{Orality and Literacy revisited}

Share This

Comments off Edit This

\subsubsection{3 | By Gregory Nagy}

I am surprised that I have never been asked the question: since Albert Lord was your mentor, and since you count yourself among those who claim to be his followers, how come you think that orality and literacy are not incompatible?

[Essay continues here...]

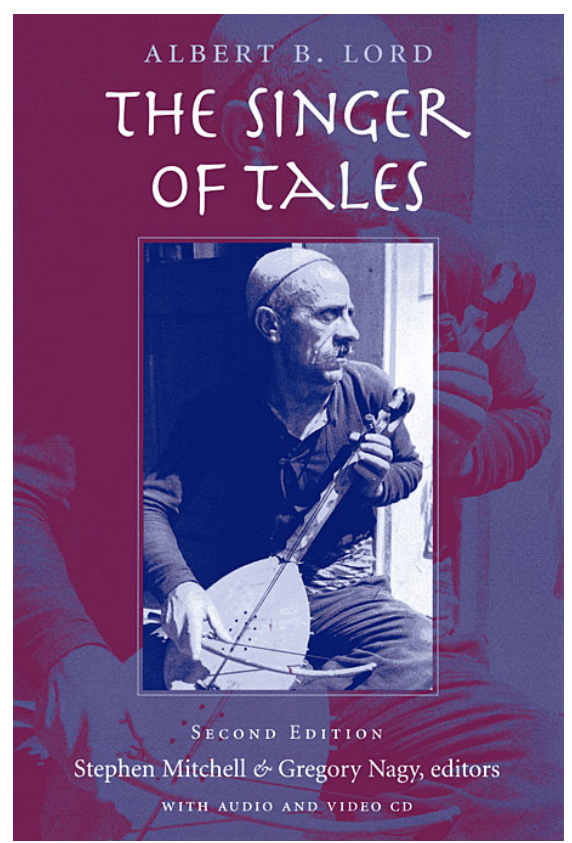

I am surprised that I have never been asked the question: since Albert Lord was your mentor, and since you count yourself among those who claim to be his followers, how come you think that orality and literacy are not incompatible? I have asked myself that question many times, and I thought I had answered it, at least for myself, in an article I published in 2001, "Orality and Literacy."

In that essay, I thought I answered the question adequately by saying, in effect, that Lord did not think that orality and literacy were universally incompatible. Lord recognized that there were indeed some incompatibilities between oral and literate aspects of verbal expression in some societies, but he resisted, especially in his later publications, any kind of universalizing formulation about some grand incompatibility between orality and literacy. I already said all this-and more-in my 2001 essay, but I now sense, so many years later, that still more needs to be said about the general question of orality and literacy. That is the reason for my revisiting the question here, though I am fully aware that whatever I say now is a far cry from the last word.

The occasion for my renewed visit is my current reading of a 2016 book by Peter Grossardt, listed in my Bibliography, about the Life of Homer traditions. The book offers a useful review of relevant facts about those traditions. Of particular interest to me are his remarks, pp. 133-134, about Aeolian populations in the general region of ancient Troy (especially with reference to the island of Tenedos and to mainland cities like Sigeion on the south side of the Hellespont as well as Sestos and Ainos on the north side). But I focus here on something else. It is what Grossardt has to say about a myth, transmitted in Vita 6 of Homer-the socalled Vita Romana (pp. 250-253 ed. Allen 1912). This myth is about the blinding of Homer by Helen, who appears to him in an epiphany and demands that he destroy what he has said about the love story of Helen and Paris=Alexandros (Vita 6 lines 51-57). Grossardt draws attention to a detail in the story as told here: in the context of her epiphany, Helen demands that Homer burn his 'poetic creations', poiēseis. Accordingly, the story presupposes the existence of a text, and it is the refusal of Homer to burn this text that leads to his blinding by an angry Helen.
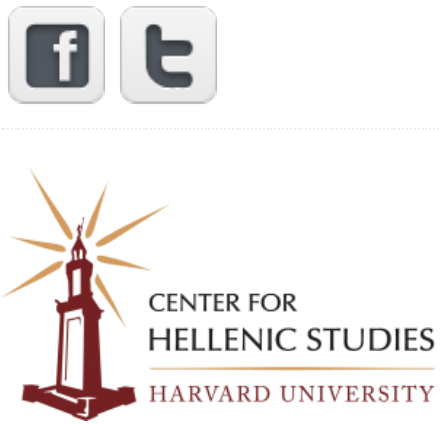

Classical Inquiries (CI) is an online, rapid-publication project of Harvard's Center for Hellenic Studies, devoted to sharing some of the latest thinking on the ancient world with researchers and the general public.

\section{Editor}

Keith Stone

kstone@chs.harvard.edu

Search for:

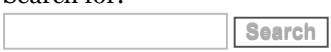

\section{Subscribe Now!}

Subscribe to this site to receive email updates about the latest research-just one or two notices per week.

EU/EEA Privacy Disclosures

Email Address

Subscribe

\section{Now Online}


Grossardt (p. 157) argues that such a prototypical text of Homer was the possession of a guild of singers in the Ionian island state of Chios, the Homēridai, who claimed genealogical or at least notional descent from Homēros 'Homer', and it was these Homēridai who supposedly mythologized such a text as the original possession of an original Homer.

This myth, which Grossardt traces back to the Ionian island of Chios, was in competition with another myth about the blinding of Homer. In this case, Grossardt traces the competing myth back to the Aeolian island of Lesbos (pp. 165-166, 175-186). Again, the source of the myth is Vita 6 of Homer (pp. 250-253 ed. Allen 1912). According to this competing myth (Vita 6 lines 45-51), Homer is a herdsman who visits the tomb of Achilles, where he prays that he may see a vision of Achilles armed with the second set of armor made for the hero by Hephaistos. Homer's prayerful wish is granted, but he is struck blind by the mere sight of Achilles, who makes his epiphany by appearing in all his martial glory, enveloped in the blinding radiance of his armor. As compensation for Homer's blindness, Thetis and the Muses bestow upon Homer the gift of poetry.

This myth about Homer's validation as poet-his Dichterweihe-is then compared by Grossardt with various examples of Irish and other north-European myths about Dichterweihe. In these myths as well, poets or would-be poets visit the tombs of heroes and, in some versions, the dead heroes respond by coming alive and directly narrating to their visitors the content of the poetry that will thereafter be mediated by the poets. On the subject of narrations as performed by dead heroes in Irish traditions, I cite especially Joseph Nagy 1997, not cited by Grossardt.

Grossardt (p. 156) refers to such myths about a poet's validation at the tomb of a hero by using the more specific term charter myth, developed by anthropologists in describing a kind of myth that aetiologizes the overall identity of whatever social group transmits such a myth (for more on working definitions of the same term charter myth, I cite Nagy 1996a:202 and 1996b:132). Grossardt (pp. 206-208) also uses the same term in referring to the story about the blinding of Homer at the tomb of Achilles, since this blinding becomes a validation of his identity as poet.

I suggest that we can go one step further and apply the same term charter myth to the story about the blinding of Homer by Helen. In that story, the detail about the refusal of Homer to destroy a prototypical text of his poetry corresponds to similar details found in Irish myths. A most striking example, analyzed by Joseph Nagy (1997), is a myth about a book about heroic deeds, named the Táin Bó Cúailnge 'Cattle-Raid of Cooley', the prototype of which had supposedly disintegrated but was then reintegrated when a visitor at the tomb of a hero experienced an apparition by that hero, who then retold for him the entire narrative content of the disintegrated book: this way, the formerly disintegrated book was reintegrated. The retelling of the story by the hero is evidently represented here as an oral tradition that is foundational for the ultimate existence of the book, the textual reality of which is of course a given. What makes the story a charter myth, however, is the fact that the existing text, which is considered to be integral, is a metaphor for the integrative power of oral traditions, which are considered to be the source of the text. In other words, the text that tells about the charter myth becomes a charter text, and the reality of that text becomes a metaphor for the reality of the myth. So, the text of the Táin Bó Cúailnge is not only a reality: it is also a metaphor for the oral traditions from which that reality evolved. Without the integrative power of oral tradition, the myth is saying, there cannot exist an integral book.

This Irish myth is duly mentioned by Grossardt (p. 200), citing some of the relevant work of Joseph Nagy (1986), who shows clearly the compatibility of oral and written traditions in medieval Ireland, but Grossardt does not cite the related work of the same Nagy (1997), already mentioned here, which explores further the metaphorization of oral traditions as an integral text.

In my own work, as in Nagy 1996b:70, I highlighted this Irish example as analyzed by the other Nagy (1986), together with an analogous Iranian example. I turn now to that Iranian example, attested in the classical Persian epic known as the Shāhnāma or 'Book of Kings', composed by the poet Ferdowsi in the late tenth and early eleventh century CE. This epic features a myth about the making of the Book of Kings in the classical Persian epic tradition. I will quote here a summary of the myth-a summary that I had put together in Nagy 1996b:70, based on work done by Davidson 1994:29-53 (3rd ed. 2013a). Here, then, is my summary (also quoted in http://classical-inquiries.chs.harvard.edu/disintegration-and-reintegration/):

According to Ferdowsi's Shāhnāma I 21.126-136, a noble vizier assembles mōbad-s, wise men who are experts in the Law of Zoroaster, from all over the Empire, and each of these mōbad-s brings with him a 'fragment' of a long-lost book of Book of Kings that had been scattered to the winds; each of the experts is called upon to recite, in turn, his respective 'fragment', and the vizier composes a book out of these recitations. [...] The vizier reassembles the old book that had been disassembled, which in turn becomes the model for the Shāhnāma 'Book of Kings' of Ferdowsi (Shāhnāma I 21.156-161). We see here paradoxically a myth about the synthesis of oral traditions that is articulated in terms of written traditions.

In this Iranian example, as in the Irish example, the text is not only a reality: it is also a metaphor for the oral traditions from which that reality evolved. Once again the formulation applies: without the integrative power of oral tradition, the myth is saying, there cannot exist an integral book.

Grossardt (p. 200) makes reference to this myth about a disintegrated and then reintegrated Book of Kings, but he does not refer to the relevant work of Davidson (1994), who has argued that

(1) this myth shows the compatibility of oral and written traditions in classical Persian poetry
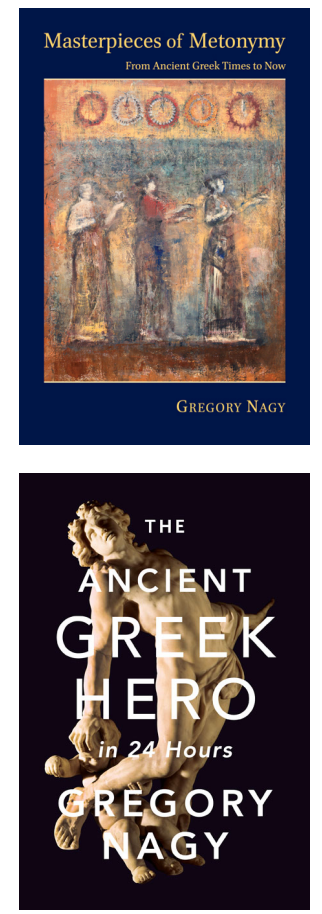

Top Posts \& Pages

The Last Words of Socrates at the Place Where He Died

Musings about a scene pictured by the Achilles Painter

Homo ludens at play with the songs of Sappho: Experiments in comparative reception theory, Part Five

\section{Most Common Tags}

Achilles Aphrodite apobatēs Ariadne

Aristotle Artemis Athena Athens

Catullus Chalcis chariot fighting

\section{Commentary Delphi}

Demodokos Dionysus etymology

Euripides Gregory Nagy H24H HAA

travel-study Helen Hera Herodotus

Hippolytus Homer

Homeric epic Iliad

Jean Bollack lament Lelantine War mimesis Minoan Empire Mycenae Odysseus

\section{Odyssey Pausanias}

Phaedra Pindar Plato Poetics Posidippus

Sappho Theseus weaving zeus

\section{Archives}


(2) classical Persian poetry is in fact an ideal example of a situation where oral and written traditions are compatible-and coexist smoothly with each other. On this point about compatibility, I recommend especially the article of Davidson 2016, which is available online.

By contrast with Davidson, Grossardt assumes that the oral and the written traditions of Persian poetry were incompatible with each other, and he questions whether it can even be said that oral poetry was a source for the text of the Book of Kings. If oral poetry was not a source, then written poetry would have to be the only source.

I see here a missed opportunity for Grossardt. If he had not assumed that oral and written traditions were incompatible, he could have easily argued that the Persian idea of a prototypical Book of Kings was parallel to the Greek idea of a prototypical text of Homer as we see it mentioned in the myth about the blinding of Homer by Helen. Further, Grossardt could also have argued that the myth about the blinding of Homer by Helen was a charter myth, just like the myth about the blinding of Homer by the gleam emanating from the armor of Achilles. In this connection, I take note of two essays I have published in Classical Inquiries about the two separate stories about the blinding of Homer. They are listed in the Bibliography as Nagy $\underline{2016.02 .18}$ and 2016.02.25.

By why is Grossardt reluctant to think in terms of a charter myth when he considers the story about the text that Homer refused to burn? It has to do with what he thinks about another story that features a text of Homer. Grossardt (pp. 199-201) thinks that the Homeric text of the so-called "Peisistratean recension" was primarily that, a text, and he doubts my argument that such a text was primarily a metaphor (as I infer from his remark at p. 201n319). Although I allow for the existence of a Homeric text in the era of Peisistratos, my central argument is that the mythologized prototype of such a text could be seen as a metaphor for the collecting of oral traditions-just like the mythologized prototypes of the Irish Táin Bó Cúailnge and of the Persian Shāhnāma.

To summarize as briefly as possible my own views on the so-called Peisistratean recension, I quote what I posted in Classical Inquiries 2017.01.27:

[The quotation starts with a reference to an epigram in Greek Anthology 11.442...] This epigram is attributed to Peisistratos, who ruled Athens during the sixth century BCE. This ruler was later demonized as a tyrant after his dynasty (known as the Peisistratidai) was replaced by the prototypically democratic régime installed in Athens by Cleisthenes toward the end of the sixth century. Back in his glory days, however, as we see in the wording of this epigram, Peisistratos was boasting that he had reassembled what are described as fragments of a body of poetry that had once been composed by Homer-and that we know today as the Homeric Iliad and Odyssey. And this body of poetry is imagined here as a corpus that had disintegrated, fallen to pieces, which were then scattered all over the region of Asia Minor. In terms of the myth propagated by Peisistratos, however, he as ruler of Athens took the initiative of reassembling the pieces and thus bringing the body of Homer back to life, as it were, every time the Homeric Iliad and Odyssey were performed "live" at the festival of the goddess Athena in Athens.

This formulation as I quoted it from the posting goes further back to my book Homer the Preclassic (Nagy 2010|2009:314-316), which in turn goes even further back to an argument I was already developing in my book Homeric Questions (Nagy 1996 chapter 3). In posts still to come, I hope to elaborate on my formulation as quoted here, linking it with the following further argument: if the written word can be used to metaphorize oral poetry in the history of Homeric reception, then it follows that the oral tradition of Homeric poetry was basically not incompatible with the written tradition designed to record it.

Such an argument, as I will explain further in posts still to come, is relevant to the title of my book Homeric Questions, published in 1996, where I already called into question the tired old use of the singular in the course of countless tedious references to "the Homeric Question." In the posts still to come, I will also have to address a related matter: it has to do with the tired old use of the word "theory" with reference to the findings of Parry and Lord about living oral traditions. How to apply those findings to the textual traditions of, say, Homer is a question of theory, yes, but the findings themselves are a matter of fact. The distinction I am making here eludes, I think, the users of such terms as "the Parry-Lord theory" or "the oral-formulaic theory" (Nagy 1996b:19-20). An egregious example is Rubanovich (2013; also already 2011:654-656).

For me, in any case, the unifying question is simply this: how to apply empirical descriptions of living oral traditions to written texts that may have originated from such oral traditions? The bibliography for the present post previews some of the works that will be relevant to that question.

\section{Bibliography}

Allen, T. W., ed. 1912. Homeri Opera V (Hymns, Cycle, fragments). Oxford.

Davidson, O. M. 1994. See Davidson 2013a.

Davidson, O. M. 1998. "The Text of Ferdowsi's Shāhnāma and the Burden of the Past." Journal of the American Oriental Society 118:63-68.

Davidson, O. M. 2000. See Davidson 2013b.
Archives Select Month $\Delta$

\section{Users}

Log out 
Davidson, O. M. 2001. "Some Iranian poetic tropes as reflected in the 'Life of Ferdowsi' traditions."

Philologica et Linguistica: Festschrift für Helmut Humbach, ed. M. G. Schmidt and W. Bisang, supplement, 1-12. Trier.

Davidson, O. M. 2002. "Haft ㅌvān." Encyclopaedia Iranica 11:516-519.

Davidson, O. M. 2005. "Persian/Iranian Epic." A Companion to Ancient Epic (ed. J. M. Foley) 264-276.

Oxford.

Davidson, O. M. 2008a. Review of Yamamoto 2003. Orientalistische Literaturzeitung 103:3:305-316.

Davidson, O. M. 2008b. "The Testing of the Shāhnāma in the "Life of Ferdowsi" Narratives." The Rhetoric of Biography: Narrating Lives in Persianate Societies (ed. L. Marlow) 11-20. Cambridge, MA.

Davidson, O. M. 2013a(/2006/1994). Poet and Hero in the Persian Book of Kings. 3rd ed. Cambridge, MA (2nd ed. Costa Mesa, CA 2006; 1st ed. Ithaca, NY 1994).

Davidson, O. M. 2013b(/2000). Comparative Literature and Classical Persian Poetics. (2nd ed. Cambridge, MA; 1st ed. Costa Mesa, CA 2000).

Davidson, O. M. 2015. "Parallel Heroic Themes in the Medieval Irish Cattle Raid of Cooley and the Medieval Persian Book of Kings," Erin and Iran: Cultural Encounters abetween the Irish and the Iranians, ed. H. E. Chehabi and G. Neville, 36-44. Cambridge, MA.

Davidson, O. M. 2016. "The Written Text as a Metaphor for the Integrity of Oral Composition in Classical Persian Traditions and Beyond." Singers and Tales in the 21st Century: The Legacies of Milman Parry and Albert Lord (ed. D. F. Elmer and P. McMurray). Classics@ Issue 14. http://nrs.harvard.edu/urn3:hlnc.essay:DavidsonO.The Written Text as a Metaphor.2016.

Davis, D. 1996. "The Problem of Ferdowsi's Sources." Journal of the American Oriental Society 116:48-57.

Elmer, D. F., and McMurray, P., eds. 2016. Singers and Tales in the 21st Century: The Legacies of Milman Parry and Albert Lord. Classics@ Issue 14. http://nrs.harvard.edu/urn-

3:hlnc.jissue:ClassicsAt.Issue14.Singers and Tales in the 21st Century.2016.

Foley, J. M. 1985. Oral-Formulaic Theory and Research: An Introduction and Annotated Bibliography. New York.

Foley, J. M., ed., 1986. Oral Tradition in Literature: Interpretation in Context. Columbia, MO

Grossardt, P. 2016. Praeconia Maeonidae magni: Studien zur Entwicklung der Homer-Vita in archaischer und klassischer Zeit. Tübingen.

Lord, A. B. 1960(/2000). The Singer of Tales. Harvard Studies in Comparative Literature 24. Cambridge MA. 2nd ed. 2000, with new Introduction, by S. A. Mitchell and G. Nagy. http://nrs.harvard.edu/urn3:hul.ebook:CHS_LordA.The_Singer_of_Tales.2000.

Lord, A. B. 1986a. "Perspectives on Recent Work on the Oral Traditional Formula." Oral Tradition 1:467503.

Lord, A. B. 1986b. "The Merging of Two Worlds: Oral and Written Poetry as Carriers of Ancient Values." In Foley 1986:19-64.

Lord, A. B. 1991. Epic Singers and Oral Tradition. Ithaca. http://nrs.harvard.edu/urn3: hul.ebook: CHS LordA.Epic Singers and Oral Tradition.1991.

Lord, A. B. 1995. The Singer Resumes the Tale (ed. M. L. Lord). Ithaca. http://nrs. harvard.edu/urn3:hul.ebook:CHS_LordA.The_Singer_Resumes_the_Tale.1995.

Nagy, G. 1996a. Poetry as Performance: Homer and Beyond. Cambridge. http://nrs. harvard.edu/urn3:hul.ebook: CHS Nagy.Poetry as Performance.1996.

Nagy, G. 1996b. Homeric Questions. Austin. http://nrs.harvard.edu/urn3:hul.ebook:CHS Nagy.Homeric Questions.1996.

Nagy, G. 2001. "Orality and Literacy." Encyclopedia of Rhetoric (ed. T. O. Sloane) 532-538. http://nrs. harvard.edu/urn-3:hInc.essay:Nag.y.Orality_and Literacy.2001.

Nagy, G. 2010|2009. Homer the Preclassic. Printed | Online version. Berkeley and Los Angeles. http://nrs.harvard.edu/urn-3:hul.ebook:CHS Nag.y.Homer the Preclassic.2009.

Nagy, G. 2016.02.18. "Just to look at all the shining bronze here, I thought I'd died and gone to heaven: Seeing bronze in the ancient Greek world." http://classical-inquiries.chs.harvard.edu/just-to-look-at-allthe-shining-bronze-here-i-thought-id-died-and-gone-to-heaven-seeing-bronze-in-the-ancient-greek-world/.

Nagy, G. 2016.02.25. "A variation on the idea of a gleam that blinded Homer." http://classicalinquiries.chs.harvard.edu/a-variation-on-the-idea-of-a-gleam-that-blinded-homer/.

Nagy, J. F. 1986. "Orality in Medieval Irish Narrative." Oral Tradition 1:272-301.

Nagy, J. F. 1997. "How the Táin Was Lost." Zeitschrift für Celtische Philologie 49-50:603-609. 
Parry, M. [1971]. The Making of Homeric Verse: The Collected Papers of Milman Parry (ed. A. Parry).

Oxford.

Reichl, K., ed., 2011. Medieval Oral Literature. Paperback ed. 2016. Berlin / Boston.

Reichl, K. 2015. "Memory and Textuality in the Orality-Literacy Continuum." In: Rubanovich 2015a:19-42.

Rubanovich, J. 2011. "Orality in Medieval Persian Literature." In: Reichl 2011:653-679.

Rubanovich, J. 2013. "The Shāhnāma and Medieval Orality: Critical Remarks on the 'Oral Poetics' Approach and New Perspectives." Middle Eastern Literatures (incorporating Edebiyat) 16:217-226.

Rubanovich, J. ed. 2015. Orality and Textuality in the Iranian World: Patterns of Interaction across the Centuries. Jerusalem Studies in Literature and Culture 19. Leiden.

Rubanovich, J. 2015b. "Introduction: New Perspectives on Orality in Iranian Studies." In: Rubanovich

2015:1-16.

Yamamoto, K. 2003. The Oral Background of Persian Epics: Storytelling and Poetry. Brill Studies in Middle Eastern Literatures 26. Leiden.

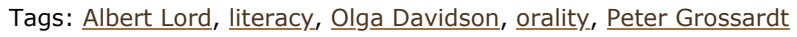

Comments are closed.

« About re-learning ideas I once learned from Roman Jakobson

Disintegration and Reintegration »

\section{(c) $(1)(9)$}

Classical Inquiries, edited by Keith Stone, is licensed under a Creative Commons Attribution-NonCommercial 4.0 International License.

$\underline{\text { EU/EEA Privacy Disclosures }} \underline{\text { Cookie Policy. }}$ CHS GR Privacy Notice

Classical Inquiries powered by WordPress and The Clear Line Theme 